\title{
Origin of calderas: discriminating between collapses and explosions
}

\author{
Izumi Yokoyama
}

The Japan Academy, Ueno Park, Tokyo, Japan

\author{
Article history \\ Received March 18, 2016; accepted November 13, 2016. \\ Subject classification: \\ Origin of calderas, Calderas of low-gravity-anomaly type, Caldera deposits, Magma reservoirs, Collapse model, Explosion \\ model, Composite calderas.
}

\begin{abstract}
Origins of calderas may differ according to their subsurface structure that may be characterized by high or low density deposits that may be observed as high or low gravity anomalies, respectively. In the Introduction, the pioneering work of Fouqué [1879] on Santorini caldera is referred to in relation to definition of calderas. First, our discussion is focused on four calderas that were seen forming during the period from 1815 (the Tambora eruption) to 1991 (the Pinatubo eruption). Coincidently, these four calderas are all low-gravity-anomaly type. Their formation processes and subsurface structure are summarized by the existing data analyzed by various authors. These results are confirmed by results of drillings at some other calderas. Then, caldera formation of both types is discussed: high-gravity-anomaly-type calderas are expected to originate from subsidence of high-density ejecta into the summit magma reservoir. On the calderas of this type, the genetic eruption believed to be accompanied by subsidences were not actually observed, and consequently three examples are mentioned only briefly. The low-gravity-anomaly-type calderas are discussed from standpoint of both the models of collapses and explosions. It is also emphasized that dynamic pressure of explosions is an important factor in the caldera formation, not only volume of the ejecta. To confirm the possibility that volcanic ejecta and edifices collapse into magma reservoirs, we discuss stress propagation from a depleted reservoir upward towards the Earth surface. Formation mechanisms of large calderas of this type are speculated; large calderas measuring about 20 $\mathrm{km}$ across may develop by successive merging of component calderas over a long period of times. A Kamchatka caldera under enlargement during the Holocene period is interpreted by successive merging of five component calderas.
\end{abstract}

\section{Introduction}

The term "collapses" means collapses or subsidences of volcanic ejecta and volcano edifices engulfed into the magma reservoirs resulting from series of violent eruptions. Here, the positions of magma reservoirs are critical. If the magma reservoirs are located at shallow depths, explosions can easily cause roofs of magma reservoirs to collapse. On the other hand, "explosions" are outward volcanic actions producing depressions, and some parts of exploded materials fall back into vents or sometimes the depressions are eroded, both resulting in formation of flat floors.

Since the early 19 th century, calderas were defined as a kind of volcanic depressions having diameters larger than $2 \mathrm{~km}$ accompanied by flat floors. This classical definition of calderas was rather primitive and vague, and has been improved by the development of Earth sciences in the last two centuries. Extensive literature exists, particularly, in the last 20 to 30 years that allows various approaches to classify calderas. A chief object in view of the present paper is reexaminations of the classification mainly from a viewpoint of geophysics.

In the early period, geologists relied mainly on surface topographies of calderas that differed from other depressions in volcanic areas. Generally, such calderas formed over long geological times and have altered due to various topographic deformations. Here, reference is made to the pioneering work of Fouqué [1879] on Santorini caldera in Greece is referred to. This caldera formed about $80 \mathrm{ka}$ BP. Around 1870 AD Fouqué visited Santorini erupting at the middle of the caldera, and he may have been immediately impressed with the precipitous caldera walls of about $300 \mathrm{~m}$ high above the sea that was different from usual crater rims. He was convinced this development was consistent with "collapse model" as indicated by the steep slopes of the escarpments. Since then, the majority of geologists may have been influenced by this idea. However, the actual slope of the caldera wall on topographic maps is about 35 degrees in arc, on the average, which is different from subjective eyesight. After a caldera forms on the sea, or on the land, its walls would continue to retreat outward by surface foundering and erosion extending 
over a lengthy period of time, repeatedly showing precipitous or gentle cliffs. Bold sea cliffs are not specific to caldera walls. The caldera walls of Santorini face to the inner sea, and hence their recession must have been very pronounced for about $80 \times 10^{3}$ years.

From geophysical standpoint, in 1969, Yokoyama and Bonasia [1978] observed the gravity anomalies on Santorini caldera as shown in Figure 1 where the anomalies are corrected for topographies. Their distribution suggests a possibility that the caldera is composed of 2 depressions, south and north. At the south, residual low anomalies amount to (about 125 to 115) $10 \mathrm{mGal}$ due to a thick deposit of low-density material conforming to the caldera boundary. If we assume a vertical fault at the western side of Thera Island, in fault-model analyses, the fault line should pass the points of the largest gradient of the anomalies, namely along the $120 \mathrm{mGal}$ contour and not the shoreline in Figure 1. Later Budetta et al. [1984] carried out a more detailed survey of gravity on the same islands and they also did not detect faults at that shoreline. Heiken and McCoy [1984, fig. 6] do not assume any faults at the basement in their geological cross sections of the caldera walls.

At Santorini caldera, Fouqué [1879] insisted on the "collapse model", in addition, mentioning the small amount of older rocks found in the pumice, but without showing any quantitative field data. This statement caused a problem for the younger generation of volcanologists. Only 4 years after Fouqué's paper, tremendous caldera-forming eruptions occurred at Krakatau. Verbeek [1885] and later researchers made efforts to estimate volume of the ejecta from the 1883 Krakatau eruption to prove validity of the collapse model. As shall be mentioned in Section 2(b), volume estimations of the pyroclastic ejecta are very difficult especially at island volcanoes and their accuracy may remain to be plus or minus an order of magnitude. Santorini caldera formed in early times, and was not observed in comparable detail as Krakatau. With these considerations mentioned above, it is difficult to easily accept Fouqué's hypothesis of "collapse model".

In the 20th century, Williams [1941] preferred classification of calderas into the following four types with their proper names as Krakatau, Kilauea, Katmai and Glen Coe. The first three calderas shall be referred to later and the last is a Tertiary basaltic "cauldron" in Scotland probably revealing a local high gravity anomaly as those in adjacent areas (cf. McQuillin and Tuson [1965]).

From geophysical standpoint, Yokoyama [1963] found low or high residual gravity anomalies on several calderas and, accordingly, classified the calderas into the two types that correspond to "Krakatau type" and "Glen Coe type" according to the classification of Williams

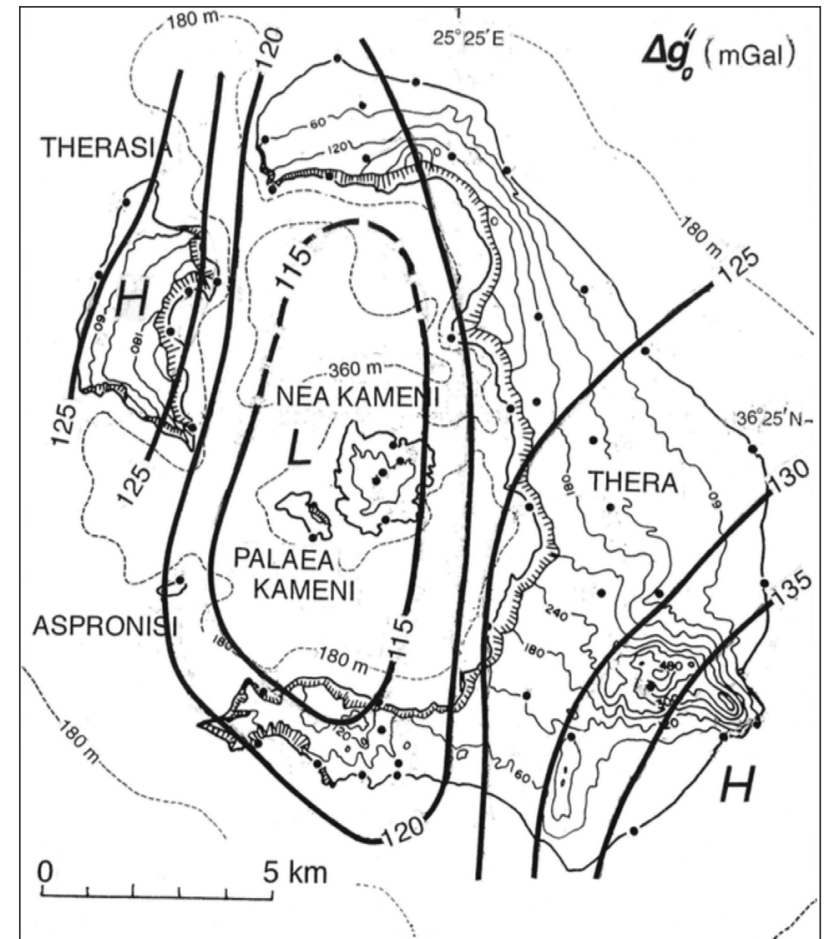

Figure 1. Santorini caldera, Greece: the Bouguer gravity anomalies are shown after Yokoyama and Bonasia [1978]. Solid dots show gravity points. $H$ and $L$ denote residual anomalies, high and low, respectively.

[1941] as mentioned above. Now, this geophysical classification that is a very simple and significant standard based on subsurface structure shall be used in the present discussion.

Calderas of Low-Gravity-Anomaly (LGA-type): the caldera deposits of low density are mainly "fallbacks" of siliceous pyroclastic ejecta and lithic breccias of the destructed volcano edifices, and develop low-gravityanomalies. Williams and McBirney [1979, p. 221] argued against this idea explaining that gravity anomaly may reveal either low or high depending on the nature of the ancestral cones and basement rocks. In fact, lithic breccias of disrupted volcano bodies also have low density due to dilatational effect: the potential theory indicates that the low gravity anomalies over a caldera are local and not due to regional structure of basements. The low gravity anomalies are characteristics of explosive caldera-forming eruptions of LGA-type beside large amounts of their juvenile ejecta.

Calderas of High-Gravity-Anomaly (HGA-type): the caldera deposits of high density are usually accumulation of basaltic lavas. At these calderas, eruptive activities are usually derived from shallow magma reservoirs, within about $5 \mathrm{~km}$ in depth. On calderas of HGA-type, roofs of the magma reservoirs gravitationally collapse or subside stepwise, to fill up gaps caused by ejection or withdrawal of lavas or magmas. This will be further discussed in Chapter 3. 
The above classification of calderas is based on their subsurface structure, and necessarily related to their formation mechanism. Hitherto, many researches have contributed to explain caldera formation. However, many of them based their discussions or experiments on the "collapse model", and uniquely, leaving the "explosion model" out of consideration. Even if they succeeded in modeling, they have to verify uniqueness of their solution. A rather recent book "Caldera Volcanism" edited by Gottsmann and Martí [2008] contains 14 papers covering various aspects of calderas and contributed by 40 active researchers. It is a pity that they scarcely refer to the four historical caldera formation, Tambora, Krakatau, Novarupta and Pinatubo, which afford main data to be discussed in the present paper.

\section{Calderas observed during their formation}

\subsection{Calderas formed after the 19th century}

The four calderas that were observed during formation, Tambora in 1815, Krakatau in 1883, Katmai in 1912 and Pinatubo in 1991 shall be emphasized because discussions on old and dissected calderas tend to be vague. Coincidently, these four calderas are all LGAtype that is much more abundant in number than the other type. Novarupta and Pinatubo calderas are not fully proved to reveal low gravity anomalies at present but may be assumed as LGA-type on the basis of funnel-shaped conduit and large amounts of juvenile silicious ejecta. By these four particular calderas alone, of course we cannot treat the great variety of different formation and structure of the calderas worldwide, and also the post-caldera activities such as resurgent doming and so on and hence we need to refer to the other calderas and volcanoes in the following discussion. Main features of the four calderas are shown in Table 1.

In this table, all the items except the last one (Ejecta volume) are observed values at the time of the caldera formation and probably reliable. "Ejecta volume" is not always unique and some estimates widely range. The ejecta from some calderas are distributed in the sur- rounding sea and, at some calderas, the ejecta surveys were carried out long time after the events, and furthermore, evaluations of their errors are rather problematic (cf. Yokoyama [2015a]). The ejecta volume is closely related to evaluation of eruption magnitude (or explosivity) as well as to dynamic pressure. "Volcanic Explosivity Index" (VEI) shall be discussed in Section 5.3. In Table 1, the largest magnitudes of earthquakes related to the events are mentioned as a possible measure of their activities. The observational conditions and the origins of the data of the four calderas are briefly summarized in the following.

(a) The 1815 Tambora eruption, Sumbawa, Indonesia This eruption was exceptionally violent but not scientifically observed. At that time, the monitoring network was not developed. We do not have any reliable research reports of this eruption. The eruption reached its paroxysm on April 10 and lasted until April 12 , producing a caldera measuring $6 \mathrm{~km}$ in diameter. On April 10, a strong shock was felt in the town of Surabaya $600 \mathrm{~km}$ away. If this was an earthquake, its magnitude (M) may have been nearly the M 7 -class (cf. Yokoyama [2001]) and it should have damaged structures considerably in the populated towns in Bali Island (at about $250 \mathrm{~km}$ distance), however, we have no particular reports of damages. Probably the strong shock was caused by air shocks. Eruptions finally ended on July 15, 1815. Later in August 1819, heavy rumbling, earthquakes and fire-phenomena were observed. A small basaltic lava dome (Doro Afi Toi) with a small lava flow may have formed from this activity.

The post-activity of the 1815 eruption is important for discussions of the total magma activity. Immediately after the caldera formation and until 1819, the magma conduit system functioned to support the faint activities within the new caldera and after that, the volcano has not shown any activity. This may suggest that the magma in the reservoir was almost depleted by the caldera-forming eruption, and totally emptied by the 1819 activity. In other words, the conduit system was

\begin{tabular}{|c|c|c|c|c|c|c|c|c|c|}
\hline \multirow{2}{*}{$\begin{array}{l}\text { Caldera } \\
\text { Tambora }\end{array}$} & \multirow{2}{*}{$\begin{array}{l}\text { Year } \\
1815\end{array}$} & \multicolumn{2}{|c|}{$\begin{array}{l}\text { Diameter } \\
\text { and depth } \\
\qquad(\mathrm{km})\end{array}$} & \multirow{2}{*}{$\begin{array}{c}\text { Previous } \\
\text { eruption } \\
?\end{array}$} & \multirow{2}{*}{$\begin{array}{c}\begin{array}{c}\text { Earthquakes } \\
\text { before } \\
\text { the event }\end{array} \\
3 \mathrm{yr}\end{array}$} & \multirow{2}{*}{$\begin{array}{c}\text { Max. earthq. } \\
\text { magnitude } \\
\text { M }\end{array}$} & \multirow{2}{*}{$\begin{array}{l}\begin{array}{c}\text { Duration } \\
\text { of climactic } \\
\text { eruption }\end{array} \\
3 \text { days }\end{array}$} & \multicolumn{2}{|c|}{$\begin{array}{c}\text { Ejecta volume } \\
\left(\mathrm{km}^{3} \mathrm{DRE}\right)+ \\
\text { missing edifices } \\
\left(\mathrm{km}^{3} \text { bulk }\right)\end{array}$} \\
\hline & & 6 & $0.6 \sim 0.7$ & & & & & $(12 \sim 60)$ & +46 \\
\hline Krakatau & 1883 & 5 & 0.25 & $1680 \mathrm{AD}$ & 99 days & 5 - class & $23 \mathrm{hr}$ & $(9 \sim 19)$ & +8 \\
\hline Novarupta & 1912 & 2 & ca. 0.25 & $?$ & 7 days & 7.0 & $14 \mathrm{hr}$ & 15 & +0.7 \\
\hline Pinatubo & 1991 & 2.5 & 0.2 & ca.1490 AD & 71 days & 5.7 & $9 \mathrm{hr}$ & 4.5 & +2.5 \\
\hline
\end{tabular}

Table 1. Main features of the four calderas observed during and after the formation. The origins of the data are given in the paragraph of each caldera. DRE: dense rock equivalent. 
not blocked by the caldera-forming eruptions in 1815 . The main conduit may have been blocked after the caldera formation, and a small basaltic lava flow probably leaked from depth after 4 years.

In 1980s, several parties carried out geological studies on Tambora. Self et al. [1984] newly estimated the total volume of the pyroclastic ejecta at $50 \mathrm{~km}^{3}$ DRE. Recently Kandlbauer and Sparks [2014] used new ash thickness data and new methods to estimate a total volume of the ejecta and obtained about $41 \pm 4 \mathrm{~km}^{3}$ DRE, made of $23 \pm 3 \mathrm{~km}^{3}$ DRE ash fall and $18 \pm 6 \mathrm{~km}^{3}$ DRE pyroclastic flows (cf. Figure 2).

\section{(b) The 1883 Krakatau eruption, Sunda, Indonesia}

This eruption was once deemed to have formed the second caldera based on earlier reports. Yokoyama [2014] disagrees with this hypothesis for two reasons: the marine depths shallowed toward the pre-caldera Krakatau Islands in the 1854 bathymetric chart (cf. Yokoyama [2014], fig. 1) and the gravity values increased similarly toward the Islands in the 1969 gravimetric map (ibid., fig. 2). These prove that the old Krakatau Islands were on a basement upheaval and did not indicate any traces of large depressions. It is important to know whether calderas can form repeatedly at the same vent or not.

On May 20, Perbuwatan, one of the parasites, began to erupt. On August 27, climactic eruptions began at the center of the islands and finally formed a submarine caldera. Coincidently, a barograph and a tide gauge in Batavia registered the eruptions. After that, in September, October, and February 1884, some activities were reported. Comprehensive research reports of the eruptions were published by Verbeek [1885] and Symons [1888], and in addition, we may refer to "Krakatau 1883: the volcanic eruption and its effects" compiled by Simkin and Fiske [1983]. In such extensive worldwide reports, it is not easy to find any facts explicitly related to "collapses".

The eruption resulted in formation of a submarine caldera having rather flat bottom about $200 \mathrm{~m}$ below sea level and after the event, in 1883 and 1884, some weak earthquake activities were reported. We have not received any report on volcanic activity at this submarine caldera. We suspect that the magma conduit system connecting to Krakatau caldera has been blocked at some depth. In 1927, 44 years after the caldera formation, Anak Krakatau erupted as a parasite, intervening between former Danan and Perbuwatan, which were both parasites of the proto-Krakatau that developed before the climactic eruptions. Anak Krakatau is a unique example of a parasite of the calderas observed during formation, and its activity is still continuing as of the 21 st century.
The new conduit to Anak Krakatau may have branched from the main conduit at a point deeper than the above-mentioned blockage. Yokoyama [2014] interpreted formation of the parasitic conduit to have branched from the main conduit at a depth of about 4 $\mathrm{km}$, based on a shear fracture model. The processes are schematically shown in Figure 2. This interpretation does not assume "caldera collapses" into the magma reservoir situated at a depth of $10 \mathrm{~km}$, but the magma conduit system used for the caldera-forming eruption was probably blockaded under the caldera deposits and the magma was supplied to the parasite through another path. According to Bemmelen [1949], the magma of the 1883 eruption was hypersthene andesitic and that of Anak Krakatau was basaltic: the Krakatau magma has differentiated in the reservoir after the caldera formation. This fact indicates that the magma reservoir has not been substantially affected by the 1883 caldera formation. Only this eruption, out of the four cases in Table 1 was not accompanied with any volcanic activity during the few years after the caldera was formed, but a new parasitic activity broke out 44 years after the caldera formation.

As for volcanic ejecta, a pioneering survey of Verbeek [1885] was carried out soon after the eruption but limited narrowly to an area around Krakatau Islands and to the flow deposits. Following Verbeek, various authors have estimated the total volume of magmatic ejecta at 9.0, 9.5, 12.2, 14.7 and $19.3 \mathrm{~km}^{3}$ DRE [Yokoyama 2015a]. Such diverse estimations are due to the differences in interpretations and data acquisitions among the various authors. This suggests that volume estimates of the pyroclastic ejecta, falls and flows, are very difficult especially at island volcanoes influenced by ocean dispersion, and their accuracy may remain to be plus or minus of an order of magnitude. In Figure 2, a probable volume of the magma reservoir is assumed to be $19 \mathrm{~km}^{3}$ [Yokoyama 2015a].

Yokoyama [2001] discussed the earthquake activity related to the 1883 eruption and concluded that the maximum magnitude of these earthquakes was in the M 5 -class and that explosive disruption released much more energy than earthquakes. The caldera was reported to have formed by collapses in the most violent explosion at 10:02, August 27 (local time). But this is doubtful since the tsunami observed near Krakatau islands all began with rises [Yokoyama 1981]: namely the tsunami was generated by upward explosions, contrary to collapses. Hence, the collapse model is not valid in this case. The second largest explosion occurred at 10:52 of the same day, and then we estimated that the climactic eruptions continued for about 50 minutes. Probably this may not be sufficient time for volcano body to collapse into the depleted magma reservoir. 

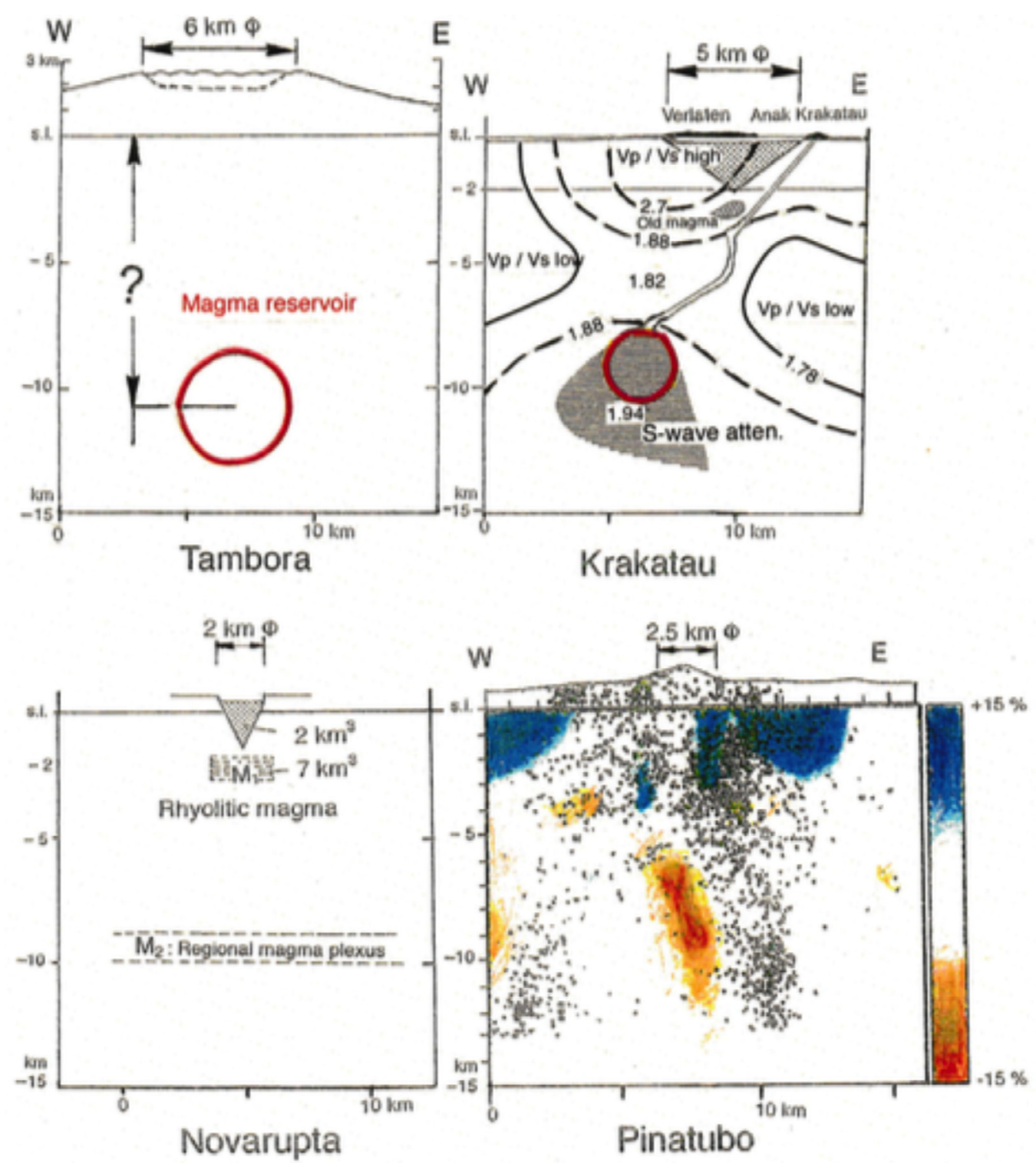

Figure 2. Proposed models of subsurface structure of the four calderas. Tambora: probable volume of a magma reservoir is shown as $41 \mathrm{~km}^{3}$ (cf. Kandlbauer and Sparks [2014]) and its depth is not determined. Krakatau (mainly by Yokoyama [2015a]): synthesized from gravity anomalies and seismological data. Dotted part consists of caldera deposits. Vp/Vs ratios are contoured and high S-wave attenuation is marked by stripes. Volume of the magma reservoir is assumed as $19 \mathrm{~km}^{3}$ (cf. Yokoyama [2015a]). Novarupta (mainly by Hidreth [1983]): $\mathrm{M}_{1}$ is a geological cross-section beneath the caldera, $\mathrm{M}_{2}$ is regional plexus of magmas in forms of sills, dikes and small chambers. Pinatubo (mainly by Mori et al. [1996]): magma bodies of $40 \sim 90 \mathrm{~km}^{3}$ are detected at a depth of $6 \sim 11 \mathrm{~km}$. The black dots represent post-eruption earthquake foci from June 29 to August 16, 1991.

(c) The 1912 Novarupta eruption, Alaska, USA

Hildreth [1983] discussed this eruption in detail and later, Hildreth and Fierstein [2012] summarized the results of various research of the 1912 eruption for centennial perspectives. The activity began with precursory earthquakes felt near Novarupta on May 31. Abe [1992] studied the Katmai and Novarupta earthquakes registered worldwide for this period: earthquakes of M7-class occurred three times in June. According to Hildreth [1983], the seismicity does not correlate with the eruptive events, and alternatively, much of the seismic activity seems to have been related to fitful subsidence of Katmai and Novarupta calderas. The explosions continued during June $6 \sim 9$ and Novarupta caldera is assumed to have formed around 13:00, June 6 (local time), simultaneously with tephra eruptions, but not with major earthquakes. In Table 1, the eruption of Novarupta is unique in having generated pyroclastic flows of a medium size in volume during climactic eruptions of a medium duration and resulted in formation of a caldera of a minimum diameter. These suggest the highest ejection rate of pyroclastic material during the caldera-forming eruption. Hildreth [1983] analyzed a flaring funnel-shaped conduit of Novarupta. Once he questioned himself whether Novarupta basin was a crater or a caldera. According to him, a blocky dacitic lava dome, $380 \mathrm{~m}$ in diameter and about $65 \mathrm{~m}$ in height was formed within the new caldera possibly several months after the last major pumice eruption. 
The magma composition did not change drastically during the period. Almost simultaneously with the Novarupta eruption, a caldera collapsed at the summit of Katmai, $10 \mathrm{~km}$ east of Novarupta. Hypothetical interpretations on the relationship between the two events were presented by the other authors in Section 4.2.

\section{(d) The 1991 Pinatubo eruption, Luzon, Philippines}

This eruption was monitored by a modern observational system. Newhall and Punongbayan [1996] compiled an interpreted research report of this eruption. Before the climactic eruptions, a lava dome (andesitic) formed near the summit of Pinatubo during June 7 to 12, 1991. This lava dome was destroyed during the climactic caldera-forming eruption of June 15 , which lasted about 9 hours. This caldera measures 2.5 $\mathrm{km}$ across, almost the minimum requirement for the definition of calderas, and ejected pyroclastics of $4.5 \mathrm{~km}^{3}$ in volume is the smallest in Table 1 . Thus, Pinatubo may stand on the boundary between the definitions of craters and calderas. Though we have no reports about gravity surveys on Pinatubo caldera, this andesitic caldera is assumed to be LGA-type because of its high explosivity and deep magmatic origin (cf. Section 4.2). About one year after caldera formation, for about 4 months during July - October 1992, a lava dome (hybrid andesite) extruded at the same position as the 1991 dome. Pinatubo formed lava domes before and after the caldera formation and both the domes are compositionally similar. This means that the caldera formation had scarcely affected the system of magma reservoir and conduit beneath Pinatubo mechanically. In short, the caldera formation was not accompanied with "collapse of the conduit". Generally, lava domes formed soon after caldera formations should not support "collapse model" considering that "collapses" should destroy the magma conduit systems and stop upward transportation of magmas. Magmas, especially viscous ones, may be difficult to pass through fragmented conduits.

According to Scott et al. [1996], the climactic eruption began at 13:42, June 15 (local time), and earthquake series of the M 5 -class started at 15:39. The strong earthquakes M 5.5 and M 5.7 occurred successively at 18:41 and 19:11. These earthquakes took place during the period of decreasing explosivity. If pre-caldera volcanoes collapse downward in a short time, we may observe earthquakes simultaneously. Scott et al. [1996] suggest that this caldera collapsed at about $16: 30$ by climactic eruptions. However, about this time, major earthquakes were not reported. They model the processes in three stages as illustrated in three figures that are similar to the explosion model. It is probable that the caldera was formed by destructive explosions lasting about 9 hours, and not by collapses of volcanic material into the magma reservoirs. Large earthquakes may result from adjustments of crustal stresses induced by magmatic activities in a wide area.

\subsection{Summary of the four calderas}

The similarity in volume between pyroclastic ejecta and disrupted volcanic edifices and the paucity of lithic fragments around the volcano are the most fundamental basis for the collapse model. It is also assumed that the latter volume compensates for the depletion of the magma reservoir caused by extrusions of magmatic material. Williams [1941] agreed with this logic and stated that this was a powerful argument in favor of the collapse hypothesis. From the above data of the four calderas of LGA-type (Table 1), the similarity does not always hold true even if we assume adequate accuracy in the volume estimation. We must recognize that volume estimate of volcanic ejecta in the field is very difficult, and estimated errors ranging over an order of magnitude should be expected [Yokoyama 2015a]. Furthermore, "caldera deposits" have been left out of consideration in the volume estimations. Even if the similarity holds true, this is not sufficient. We should prove the mechanism by which collapsed material of the volcano edifices reach magma reservoirs through magma conduit systems.

The diameters of calderas are not strictly proportional to the volume of their ejecta as shown in Table 1 . This may be because explosivity or eruption magnitude depends on the explosion pressure, as well as the mass of the ejecta. We know many calderas larger than the four calderas in diameter, and we suggest a kind of partial overlapping of small calderas to form larger ones (cf. Section 5.4).

In Table 1, formation of the four calderas was completed no later than the end of the eruptions within 3 days (Tambora), $23 \mathrm{hr}$ (Krakatau), $14 \mathrm{hr}$ (Novarupta) and $9 \mathrm{hr}$ (Pinatubo). If "collapse model" assumes that collapses occur during violent explosions, it should be very difficult for crushed volcanic bodies to collapse downward against the upward force of the violent explosions. In fact, it cannot be absolutely certain that "collapses" occur during eruptions in all the cases.

\section{Formation of HGA-type calderas}

The four calderas observed during their formation coincidentally belong to the LGA-type. Here we discuss formation of HGA-type calderas independently of the above-mentioned calderas. Unfortunately we have no historical data or direct observations on the formation of HGA-type calderas because their development would proceed gradually or stepwise over long periods. 
Therefore, we refer to ensuing events from the original caldera formation. At the calderas of this type, the deposits of high density are usually composed of accumulation of basaltic lavas. And their eruptive activities are usually derived from shallow magma reservoirs located within $5 \mathrm{~km}$ of depth. At calderas of this type, roofs of the magma reservoirs would collapse gravitationally to fill gaps caused by ejections or withdrawals of magma through lava flows. The following are two examples of similar collapses that are not caldera formation but occur as collapse stages of structure that we finally consider HGA-type calderas. The last (Miyake volcano) is from the genetic stage of caldera formation of the same type. Dimensions of calderas of this type are not related to their explosivity, and not so large because their origins are relatively shallow.

(a) The 1924 eruption of Halemaumau crater in Kilauea caldera, Hawaii

A major collapse of Kilauea caldera and related volcanic and tectonic events occurred in 1790. A smaller collapse accompanied by low explosivity occurred at Kilauea caldera in 1924 and the caldera floor was lowered of about $270 \mathrm{~m}$. The subsidence occurred for 3 months while the multiple steam explosions occurred for 18 days within a month. Decker [1987] pointed out that the volume rate of magma removal was limited and the process of caldera collapse went on over periods of a few months and interpreted the caldera-collapses as a result of steam explosions caused by contacts between molten lava filling the crater and the aquifer. The explosions blew off the caldera material including molten lava and the fallback rubble deposited in the crater at the deeper level than previous one. As a result, the explosions caused subsidence of the caldera floor. A shallow magma reservoir was an indispensable condition for the caldera collapse at Kilauea caldera.

(b) The 1968 eruption of Fernandina caldera, Galapagos Islands, Ecuador

The caldera measures about $6 \times 4 \mathrm{~km}^{2}$. In early June 1968, a small eruption occurred at the flank and was followed by a small explosion with ash-falls at the summit caldera rim. Accompanying earthquake swarms continued for about 10 days. On June 21, the existing caldera bottom, with a surface area of about $8 \mathrm{~km}^{2}$, subsided about $300 \mathrm{~m}$ [Filson et al. 1973]. There was no evidence of new lavas. Small eruptions and earthquake swarms may have triggered the gravitational subsidence.

Hawaiian and Galapagos calderas are named "basaltic lava-flow calderas" by Lipman [1997]. These calderas are classified to HGA-type by their subsurface structure.

\section{(c) The 2000 eruption of Miyake volcano, Japan}

This volcano island is composed of basaltic rocks. On June 27, a small submarine eruption occurred at a distance of $1.2 \mathrm{~km}$ west of Miyake Island. By the shear fracture model [Yokoyama 2015b], this parasitic vent is assumed to have branched from the main vent at a depth of about $6 \mathrm{~km}$ beneath the center of the volcano, determined by taking the radial distance of the parasite vent from the center of the main vent at $5 \mathrm{~km}$. The above branch point is not necessarily at the magma reservoir. On July 8, magma pressure beneath the volcano may have triggered volcanic earthquakes of $\mathrm{M} 2 \sim 3$, resulting in the summit eruptions. Simultaneously, the cylindrical summit part measuring about $900 \mathrm{~m}$ in diameter and $190 \mathrm{~m}$ in depth collapsed forming a summit depression. Geshi and Oikawa [2008] estimated volume of the tephra erupted as $1 \times 10^{7} \mathrm{~m}^{3} \mathrm{DRE}$, corresponding to only $1.7 \%$ of the total volume of the depression: this means that the summit collapse of Miyake volcano in 2000 had minimal relation to the magma ejections, and may have been caused by internal removal of magmas from the summit part. Before the eruption, there was a shallow pit of about $200 \mathrm{~m}$ in diameter at the summit, and the residual Bouguer gravity anomaly around there showed a tendency to be high [Yokoyama 2002]. From a long-ranged viewpoint, Miyake volcano may repeat such gravitational subsidence and grow to form a caldera of HGA-type. Similar convulsions may have been repeated on the adjacent Ooshima volcano island, $60 \mathrm{~km}$ away, that has a typical HGA-type caldera at its summit, and its magma reservoirs are situated around two depths of 5 and $10 \mathrm{~km}$.

Among the three eruptions discussed in this chapter, shallow summit reservoirs and basaltic magmas of high density and low viscosity are common. Notably, collapses that occurred in response to removals of basaltic lavas or magma beneath summit craters or portions of the volcano, originate HGA-type calderas.

\section{Structure of LGA-type calderas}

Calderas of this type are generally large in diameter, and accordingly, their structure will be on larger scale. In order to interpret formation mechanisms of LGA-type calderas, the author will discuss both surface and subsurface structure of the calderas. And to confirm the interpretation, drilling results at some other calderas shall be referred to. In general, the geomorphologic characteristics of calderas common to both HGA- and LGA-types, are precipitous caldera walls and flat caldera floors. For caldera walls, a pertinent discussion is made in the Introduction exemplifying Santorini caldera. And the latter characteristic, caldera deposits with flat floors are much more abundant in LGA-type 
calderas because of their larger dimension. Hence, they shall be mentioned in the following section.

\subsection{Caldera deposits}

Generally speaking, the residual gravity anomalies observed on and around calderas provide us useful knowledge on the caldera deposits and their boundaries. The gravity anomalies observed on LGA-type calderas suggest funnel-shape caldera deposits of low density, and such structures are verified by drilling results at some calderas. At Krakatau caldera, Yokoyama [2014] determined the funnel-shape of caldera deposits by gravimetries, whereas the bathymetric charts show that the maximum gradient of the caldera wall at SE of Verlaten Island is about 40 degrees in arc, not very steep and suggests a funnel-shaped depression. The northward precipice of Rakata Island is not located on the caldera rim and was formed by explosive breakdowns from the 1883 eruption. As for Novarupta, from topographical observations, Hildreth [1983] inferred a flaring funnel-shaped vent (cf. Figure 2) probably produced by explosions.

Almost all calderas have flat floors overlying caldera deposits, large or small in area. The deposits are usually composed of "fallbacks" of juvenile ejecta and lithic breccias, both being of low density. Flat caldera floors are usually one of the characteristics of calderas, distinguishing them from volcanic craters. At both Novarupta and Pinatubo calderas, post-eruptive domes developed at their bottoms as mentioned before. We believe such dome formation is a possible consequence of the calderic event.

4.2. Subsurface structure of the four calderas with emphasis on magma reservoirs

Magma reservoirs are storage locations where magmas differentiate and are extruded out causing volcanic eruptions. Their depths and configurations are closely related to caldera formations. Geophysical techniques of locating magma reservoirs are expanding with time. The results of some recent researches are shown in Figure 2 which indicates that the LGA-type calderas are probably not underlain by shallow magma reservoirs.

(a) Tambora: no geophysical discussions on subsurface structure have been reported. After the 1815 eruption, the volcano has not discharged significant amount of magma, except from a small activity in 1819 . If we assume that the magma stored in the reservoir was totally ejected by the 1815 eruption, volume of the reservoir is larger than that of Krakatau in proportion to volume of the ejecta. We have no data related to the depth of the reservoir. Only, volume of a magma reservoir assumed from the ejecta volume is shown in the figure. (b) Krakatau: since 1960s, geophysical research has been carried out on and around Krakatau Islands. Yokoyama [1981] proposed a model of subsurface structure of this caldera mainly from gravity anomalies. He assumed presence of caldera infilling deposits and tentatively estimated the depth of the reservoir at about $5 \mathrm{~km}$. Later, the bathymetries and gravimetries on land and sea clarified the subsurface structure beneath the caldera. Ranging in the time-span from 1984 to 2006 , temporary seismological observations were made to estimate seismic $S$-wave attenuation [Harjono et al. 1989] and $\mathrm{V}_{\mathrm{p}} / \mathrm{V}_{\mathrm{s}}$ variations [Jaxybulatov et al. 2011], and both properties indicated the presence of fluid believed to be magma probably coinciding with the 1883 reservoir. Yokoyama [2015a] synthesized these results as shown in Figure 2, where the caldera deposits are saturated in sea water producing very high $\mathrm{V}_{\mathrm{p}} / \mathrm{V}_{\mathrm{s}}$ ratios. This supports existence and origin of caldera deposits at Krakatau. Also, both authors similarly located magma reservoir beneath Krakatau caldera at a depth of about $9 \mathrm{~km}$. In 1927, Anak Krakatau erupted at the caldera rim as a parasite of Krakatau volcano. The magma conduit for the parasite branched from the main vent at a depth of about $4 \mathrm{~km}$ [Yokoyama 2014] and the resulting parasitic volcano has been intermittently active in the 21 st century.

(c) Novarupta: Hildreth [1983] studied ash-fall and ash-flow deposits from Novarupta caldera and derived his geological interpretation of the shallow system or magma stop $\left(M_{1}\right.$ : rhyolitic magma) shown in Figure 2. His caldera model assumes caldera deposits of $2 \mathrm{~km}^{3}$ in volume, and also assumes the magmatic plumbing system $\left(\mathrm{M}_{2}\right.$ : andesitic and dacitic magma) beneath the Katmai area. Ward et al. [1991] suggest the system more likely to be a plexus of dikes, sills, and small chambers, rather than one large uniform magma chamber, from their seismometric results. These may be located at a depth $\leqq 10 \mathrm{~km}$ beneath a regional area based on the observations made by Matumoto [1971, fig. 6].

As for the relationship between the two calderas, Katmai and Novarupta, Eichelberger and Izbekov [2000] made an assumption that magma was transported to the shallow chamber beneath Novarupta through planar dikes rising from depths. And Hildreth and Fierstein [2000] proposed that all magmas related to the Katmai-Novarupta eruption were stored under Katmai. Later, Yokoyama [2015b] proposed a mechanical interpretation applying the shear fracture model: the depth (D) of the pressure source is obtained from 1.2 times $r$, where $r$ denotes radial distance of the surface vent from Katmai $(10 \mathrm{~km})$. This means that the conduit for Novarupta branched from a depth of about $12 \mathrm{~km}$ beneath Katmai volcano, and may have been accom- 
panied with major earthquakes. Evaluation of the structures through petrological data may help distinguish the above hypotheses.

(d) Pinatubo: Mori et al. [1996] observed volcanic earthquakes following the climactic eruptions of June 15, 1991, and obtained the distribution of seismic Pwave dissipation by means of velocity inversion. A cross section of the velocity perturbations from the average velocity is shown in Figure 2 where a low velocity zone between $6 \sim 11 \mathrm{~km}$ in depth is inferred to be a magma reservoir. This is one of the most accurate localization of magma reservoirs beneath active volcanoes in the last century, and this suggests possible variety in the configuration of the chambers.

In short, the above examples show that reservoirs of silicic magmas were located at depths between 5 and $10 \mathrm{~km}$ beneath the above-mentioned volcanoes. In the following discussion, this will be the presupposed characteristic of LGA-type calderas.

\subsection{Results of drillings at some calderas of LGA-type}

To study subsurface structure of calderas, various geophysical investigations are fundamentally necessary, and to confirm their results, drillings are very useful as the drill cores ultimately give a definitive geologic cross section in depths. No drillings have been carried out at the four calderas in question. At calderas of LGA-type, deposits of low-density are mainly composed of silicic pyroclastic ejecta, and partly, portions of volcano edifices. Results of drillings at some calderas may afford us specific information about the physical state and chemical composition of the deposit material and may help to analogize with the other calderas of the same type.

(a) Aso caldera, Kyushu, Japan: Yokoyama [2014] previously reported the results of drillings near the center of the caldera (symbol $\oplus$ in Figure 3a) that penetrated the $500 \mathrm{~m}$ thick layer of welded pyroclastic flow deposits [Hoshizumi et al. 1997]. These results indicate that the profile of Aso caldera is funnel-shaped and its caldera deposits are mainly composed of fallbacks, at least, at the drilling sites.

(b) La Primavera caldera, Mexico: this caldera measures $13 \mathrm{~km}$ in diameter. Since 1980, the Comisión Federal de Electricidad of Mexico has drilled 13 geothermal wells reaching depths of $668 \sim 2986 \mathrm{~m}$ around the center of the caldera. The drill cores provide definitive depth-section of the underlying deposits. The caldera deposits are mainly pyroclastics and partly mixed with lithified tuff layers. Beneath the caldera deposits, there are basements of compact granite at a depth of about $3 \mathrm{~km}$. Yokoyama and Mena [1991] determined the structure of the caldera combining the drilling results with gravity anomalies which are composed of two relative lows amounting to 14 and $9 \mathrm{mGal}$ : the caldera basement is composed of partially overlapped depressions, about 1.5 and $1 \mathrm{~km}$ deep (cf. 5.4. Composite calderas).

(c) Guayabo caldera, Costa Rica: this caldera lies between young stratocones and measures $11 \mathrm{~km}$ in diameter and forms a caldera lake. Halliman and Brown [1995] carried out micro-gravity surveys and examined stratigraphy to a depth of $2200 \mathrm{~m}$ at 11 boreholes within this caldera. The caldera is LGA-type with a Vshaped gravity anomaly. According to them, the gravity anomaly is related to the caldera fills of low density and not to brecciated caldera basement, and the caldera was originally formed in funnel-shape, and not pistontype subsidence, that later collapsed incrementally, and stratocones grew within the caldera.

In conclusion, the results of sufficiently deep drillings carried out at several calderas of LGA-type verify that caldera deposits are underlain with basement rocks and the basements appear funnel-shaped. Caldera deposits are mostly composed of low density infilling deposits, made of pyroclastics and lithic breccias. Furthermore, it has been established by these studies that summit magma reservoirs do not exist directly beneath the calderas of LGA-type.

\section{Formation of LGA-type calderas}

In the following, formation mechanism of LGAtype calderas shall be interpreted on the basis of subsurface structure as discussed in the previous section. First, modeling of caldera formation characteristic of studying LGA-type calderas is mentioned, and two hypotheses of caldera formation of the same type are separately discussed. Last the discussion is extended to composite calderas.

\subsection{Modeling of caldera formation}

In nature, caldera-forming eruptions of LGA-type are all extraordinarily explosive accompanying tremendous amounts of juvenile ejecta. At present, modeling of volcanic explosions is impracticable, and so the modeling of "collapses into magma reservoirs" cannot totally simulate the natural processes of formation of LGAtype calderas.

Generally speaking, for physical modeling, the law of similarity between natural objectives and experimental media (usually fluid) should be provided. Otherwise, the results remain only as qualitative deduction. Modeling of caldera formation, whether experimental or numerical, should set the initial conditions. However, at present, the conditions are too much simplified in many cases.

Fundamental conditions for modeling of caldera formation are concerned in crustal structure beneath 
volcanoes (geological properties and mechanical strength), and furthermore magma reservoirs (depths and configurations): the latter has not been established except for very few calderas and so we should make allowances in interpreting the results of the modeling.

Experimental modeling: for an example, Roche et al. [2000] carried out experimental study of caldera formation with considerations of scaling. They intended to clarify the depression of the Earth surface caused by magmatic and hydrostatic pressure and adopted models of shallow reservoirs with flat tops.

Numerical modeling: for an example, Gregg et al. [2012] studied caldera-forming eruptions by viscoelastic numerical models following the general elastic model formulation. They developed a model of magma reservoirs beneath caldera volcanoes as an ellipsoid at relatively shallow depths. Their results show two cases of triggering eruptions of magma reservoirs according to the dimensions of the reservoirs: (1) dike fractures at the magma reservoir boundary, and (2) fault fracture within the crust. Alternatively, the point of their argument covers eruption mechanism related to the explosion model of caldera formation.

The initial conditions of both of the above modeling are not always similar to the actual volcanism. Modeling study of caldera formation should be first applied to the four calderas observed during their formation (Chapter 2), because such modeling may need fewer assumptions than the prehistoric ones.

\section{a caldera"}

5.2. Hypothesis: "Collapses into a magma reservoir form

In order to coordinate the long disputed problem on the formation of LGA-type calderas, we consider the two main hypotheses in the following. The first hypothesis is concerned with "collapses". This mechanism is consistent with that of HGA-type caldera as discussed in Chapter 3. Here its application to LGAtype calderas shall be discussed. The concept of "collapse model" has been determined with the assumption that the total volume (DRE) of pyroclastic ejecta from a caldera-forming eruption is equal to the volume of disrupted volcano edifices, and that lithic breccias of volcano edifices are not found around the caldera. This has been long disputed by many researchers. Yokoyama [2015a] reexamined this concept for the 1883 caldera formation of Krakatau and did not agree because the volume estimate of volcanic ejecta requires an allowance of about an order of magnitude, and we cannot prove parity between the two. Lipman [1997] discussed subsidence of ash-flow calderas presenting a caldera model that is characterized by rather thick and funnel-shaped layer of tuff fills. He interpreted many examples and corresponding models, but depths and configuration of the magma reservoirs remain arbitrary. The LGA is derived from the caldera fills or fallbacks composed of juvenile ejecta and lithic breccias, all being low density (cf. Section 4.1).

As for magma reservoirs, the present author postulates that they are composed of sills and dykes, similar to that proposed by Fisk and Kinoshita [1969] in their description of the 1967 1968 activity of Kilauea volcano, Hawaii. A magma reservoir of similar constitution is assumed beneath Novarupta caldera (cf. Section 4.2). At such reservoirs, magma ejection is possible while magma withdrawal may be rather difficult. When a deep magma reservoir is emptied by eruptions partly or totally, the reservoir should be crushed immediately by lithostatic pressure and any mechanical effects should propagate outward from the reservoir as shown in the next.

Stress propagation from crushed magma reservoirs: possibility of collapses of volcano bodies into magma reservoirs depends on the depth of the reservoirs. When the reservoirs are located near the surface as in the case of calderas of HGA-type (Chapter 3), volcanic bodies destructed by explosions may collapse into the reservoirs. However, probable depths of magma reservoirs of silicic magmas are estimated at $5 \sim 10 \mathrm{~km}$ as shown in Section 4.2 and so it is doubtful that destructed volcanic edifices can reach the magma reservoir in opposition to the outward explosive force during caldera-forming eruptions. Apart from the collapse process itself, stress changes around a magma reservoir caused by magma discharge should be an obstructive factor to the collapse processes. A similar discussion by Yokoyama [2015a] shall be briefly summarized in the following.

For the sake of simplicity, we assume crushing force $F$ to act concentrically at the center of a cavity that is the remnant of a reservoir, and to reach maximum instantly. Timoshenko and Goodier [1970] discussed "Force at a point in an infinite solid", and their results are qualitatively applicable to the present problem. Beginning with the Laplace's equation, they derived the vertical stress in polar co-ordinates (the origin is the center of the cavity) as

$$
\begin{aligned}
\sigma_{\mathrm{z}}= & F\left\{(1-2 v) z\left(\mathrm{r}^{2}+\mathrm{z}^{2}\right)^{-3 / 2}+\right. \\
& \left.+3 \mathrm{z}^{3}\left(\mathrm{r}^{2}+\mathrm{z}^{2}\right)^{-5 / 2}\right\} / 8 \pi(1-v)
\end{aligned}
$$

Along the vertical axis, Poisson's ratio $v$ is canceled and the stress distribution is given as

$$
\sigma_{z, \mathrm{r}=0}=F / 4 \pi \mathrm{z}^{2}
$$

Qualitatively, the stress induced by the crushing of a magma reservoir should decrease rapidly in inverse 
proportion to $z^{2} . F$ in the above formulae is a concentrated force and acts simultaneously with discharge of magma. Magma reservoirs of LGA-type are most probably located at a depth of around $5 \sim 10 \mathrm{~km}$, as mentioned in Section 4.2. Under such conditions, the reservoir should be crushed by lithostatic pressure as the magma is discharged by eruptions, provided that magma conduits have no influence on the above processes. Then, the stress due to the crushing shall dissipate upward and instantly with almost no effect on the surface. In short, destructive stress caused by magma discharge from a reservoir at a sufficient depth does not normally reach the Earth surface. Now the collapse model should explain the mechanism of transfers of shattered materials from the Earth surface to a deep magma reservoir.

As a result, the hypothesis "Collapses into a magma reservoir form a caldera" is not agreement for formation of LGA-type calderas unless their magma reservoirs are located at shallow depths and the mechanism for crushed volcano bodies to reach the reservoir is logically interpreted.

\subsection{Hypothesis: "Destructive explosions form a caldera"}

Originally destructivity of volcanic eruptions is evaluated by dynamic energy of eruption that is expressed by mass of ejecta combined with ejection pressure. Such dynamic energy accumulated in the Earth crust is limited due to the elastic limit of the crust.

Explosion energy and formation of calderas: explosivity, or eruption magnitude, is defined by dynamic pressure of the explosions which is proportional to (mass of ejecta) $\times(\text { velocity of ejecta })^{2}$. Eruption scale was first discussed by Tsuya [1955] who classified volcanic ejecta according to volume and type: the type distinguishes the ejecta into three categories: lava-flows, fragmentary ejecta only, and ejecta dominated by old detritus. The kind of ejecta is related to (velocity of ejecta) and thermal energy, but their quantitative estimations are actually difficult. Later, Newhall and Self [1982] proposed "Volcanic Explosivity Index" (VEI) that actually classifies explosivity by the order of magnitude of tephra volume and by column height from the explosions that is a factor of dynamic pressure, though its quantitative estimation is possible only for present-day eruptions. Caldera-forming eruptions should be positively characterized by extraordinarily high dynamic pressure, not only large volume of the ejecta. Tsunamis and air waves caused by volcanic eruptions are typical phenomena of tremendously large dynamic pressure. Caldera-forming eruptions should be evaluated by their power not only by ejecta volume.

Eruption magnitude has the upper limit that is usually assigned to the 1815 eruption of Tambora. On the other hand, the highest limit of the earthquake magnitude related to volcanic eruptions is M7, as instrumentally observed in the 1912 eruption of Novarupta and the 1914 eruption of Sakurajima. Volcanological meaning of earthquakes of the M 7-class has been not fully interpreted, but they may be due to readjustment of crustal stresses caused by large volcanic eruptions. Empirically, they are not always indicative of caldera formation (cf. Table 1).

Steinberg [1974] discussed the theory of strong throw-out blasts and the results in the 1956 eruption of Bezymianny volcano, Kamchatka, observed by Gorshkov [1959], and concluded that the largest volcanic explosion with the total energy of $5 \times 10^{18}$ Joules, corresponding to an earthquake of $\mathrm{M} 9$, can produce a crater of $10 \mathrm{~km}$ in diameter maximum, on the assumption that the center of the explosion is situated at the optimum depth. The above energy is derived from the total energy of the explosion and ejected material. In contrast, meteoric craters may have much larger diameters because of their higher impact energy. In Table 1 , the maximum diameter of the four calderas is $6 \mathrm{~km}$ at Tambora. This may suggest validity of Steinberg's estimation. Many calderas measuring more than $10 \mathrm{~km}$ across may have been produced by merging of adjacent and smaller component calderas. This shall be mentioned later, in Section 5.4.

Gigantic eruptions observed during crater formation: main eruption data of the four calderas, Tambora, Krakatau, Novarupta and Pinatubo, are listed in Table 1. They were all large eruptions forming calderas of diameters ranging from 2 to $6 \mathrm{~km}$. Beside these calderas, we know two examples of gigantic eruptions observed during crater formation in the 20th century: the Bezymianny and Mt. St Helens eruptions. The 1956 event at Bezymianny volcano ejected ashes and an agglomerate flow of $1.8 \mathrm{~km}^{3}$ bulk with the maximum column height of about $45 \mathrm{~km}$, forming a crater measuring $1.5 \times 2 \mathrm{~km}^{2}$ in dimension. Gorshkov [1959] estimated its explosion pressure at $3000 \mathrm{~atm}$. that is equal to lithostatic pressure of about $11 \mathrm{~km}$ in depth. And, the 1980 event at Mt. St Helens ejected $0.2 \mathrm{~km}^{3}$ DRE of tephra, with the maximum column height was about 14 24 $\mathrm{km}$, forming a crater measuring $2 \mathrm{~km}$ across (cf. Lipman and Mullineaux [1981]). These two eruptions were extraordinarily explosive with high velocity of ejecta and exploded the upper parts, but their volume was rather small, and consequently resulted in formation of relatively small craters. On the other hand, according to the classical definition, they may be just called calderas. If these two eruptions were accompanied with large amounts of juvenile ejecta, they may have formed proper calderas. In this respect, ejecta volume is one of 
the important factors for caldera formation. Gigantic explosions accompanied by a large amount of pyroclastic ejecta mainly contribute to formation of calderas, larger than $2 \mathrm{~km}$ and maximum of $10 \mathrm{~km}$ in diameter. Then, it may be assumable that large calderas, such as Aso, Aira, Lake Toba and others, are formed through the amalgamation of $2 \sim 3$ smaller calderas as shall be discussed in the next section.

As a result, the hypothesis "Destructive explosions form a caldera" is in agreement with formation of LGAtype calderas.

\subsection{Composite calderas}

Worldwide, there are many calderas with large diameter (about $20 \mathrm{~km}$ ). If we adopt the explosion model, the dimensions of the resulting depressions have an upper limit of about $10 \mathrm{~km}$ in diameter, as mentioned in the previous section. Calderas usually expand outward by foundering and erosion of caldera walls over long periods of time. Sometimes, a new caldera would be produced adjacent to an existing caldera and the two calderas eventually may be combined into a larger caldera. This is a "composite caldera". Therefore, our hypothesis is that calderas of large diameter (around $20 \mathrm{~km}$ ) result from the merging of various smaller calderas. In this paper, we have called these various portions of the large caldera: "component calderas". We may possibly distinguish "component calderas" by using gravity anomalies or topographic features. For an example, Santorini caldera shown in Figure 1 may be composed of the north and south component calderas judged by the topographies, and the south vent is active at present. In the following, three large calderas Aso and Aira in Kyushu, Japan and Toba in Sumatra shall be mentioned as typical examples. The first two calderas are located at about $150 \mathrm{~km}$ apart and have no direct influence with each other in volcanic activity.

(a) Aso caldera, Kyushu: measures $15 \times 20 \mathrm{~km}^{2}$ in dimension. Komazawa [1995] carried out precise gravity surveys on and around this caldera, and analyzed the observed Bouguer anomalies quantitatively, applying frequency analyses and filtering and achieved the residual anomalies of a shallow structure, comparable to a structure shallower than $5 \mathrm{~km}$. Such gravity anomalies disclose the subsurface structure covered by topographic features. Thus, the anomalies in Aso caldera are composed of five lows of residual gravity anomalies ranging $5 \sim 10 \mathrm{mGal}$, and the small and large dimension are marked by (1) in Figure 3a. The three blocks of small gravity anomalies in the northern part are derived from three nested depressions, and collectively are represented by one component caldera $(* N)$. Thus, we as-
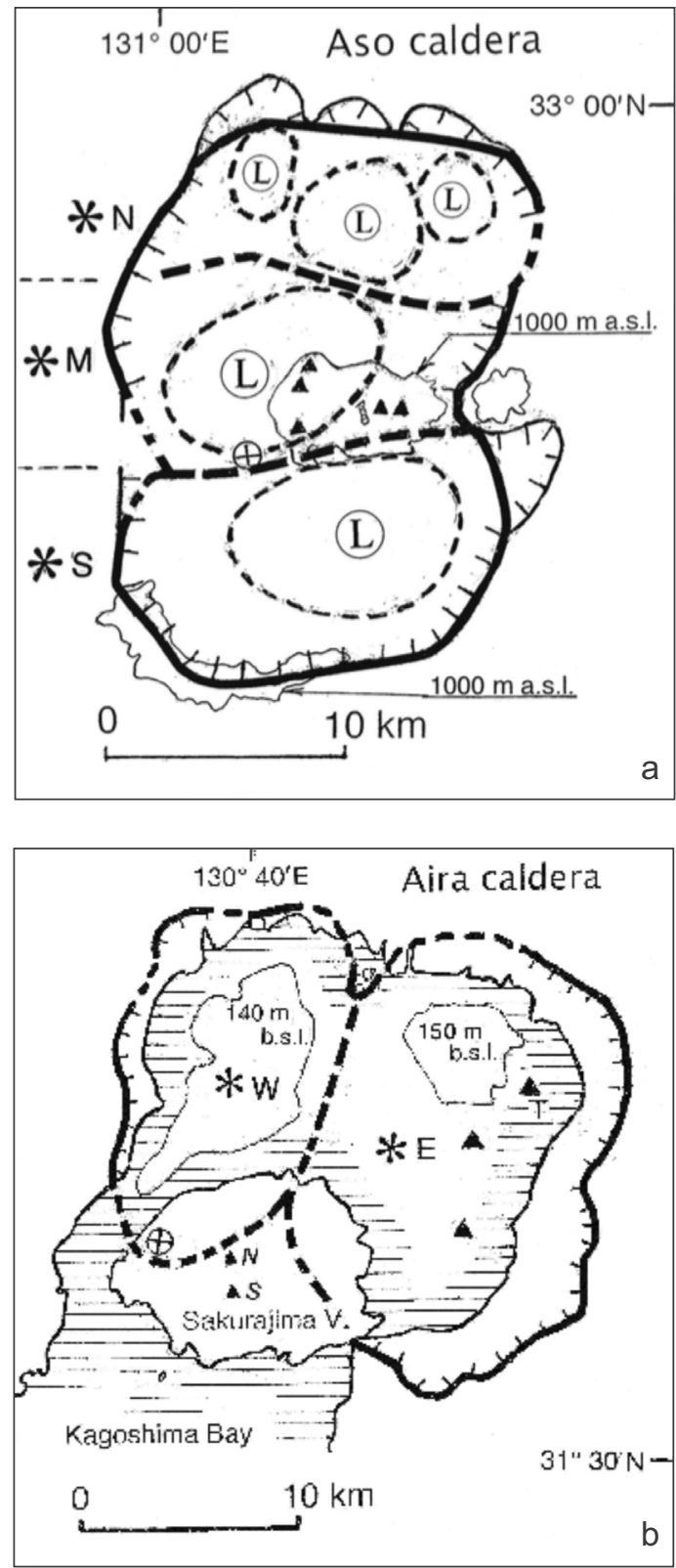

Figure 3. Composite calderas in Kyushu, Japan, Aso and Aira: hatchured contours indicate the present caldera rims. $\oplus$ denotes drilling sites. Thick solid lines outline the caldera formed by amalgamation of component calderas. (a) Aso: (1) denotes a residual low gravity anomaly and triangles denote active cones. $(* \mathrm{~N}),(* \mathrm{M})$ and (*S) are component calderas and amalgamated to form Aso caldera. (b) Aira: thin outlines in the sea area of both $(* \mathrm{~W})$ and $(* \mathrm{E})$ show flat bottoms, respectively. Triangles in $(* \mathrm{E})$ are vents: "T" is active and another two are extinct. $\mathrm{N}$ and $\mathrm{S}$ on Sakurajima volcano denote extinct North Peak and active South Peak, respectively.

sume Aso caldera is composed of three component calderas, $(* \mathrm{~N}),(* \mathrm{M})$ and $(* \mathrm{~S})$. At present, we cannot exactly determine the order of formation of the three component calderas.

Pyroclastic flows and falls from Aso caldera have occurred four times since $300 \mathrm{ka} \mathrm{BP}$, "Aso-1" (ca. $270 \mathrm{ka}$ $\mathrm{BP}$ ) to "Aso-4" (ca. $80 \mathrm{ka} \mathrm{BP}$ ), and the last one was the largest, amounting to about $400 \mathrm{~km}^{3}$ bulk in volume of the fall deposits. Symbol $\oplus$ at the southern rim of re- 
gion $(* \mathrm{M})$ denotes a group of boreholes which detected the Aso-4 deposits at roughly between 1000 1500 m depth from the caldera surface, as mentioned in Section 4.3. This suggests that the caldera deposits in component caldera $(* \mathrm{M})$ are composed of considerable amount of the "fallbacks" from pyroclastics "Aso-4". Such conditions may be found at other LGA-type calderas. At Aso caldera, if these fallbacks were found in the whole area of $(* \mathrm{M})$, their volume should amount to roughly $25 \mathrm{~km}^{3}$ in bulk. This may be not a negligible quantity and is suggestive of formation mechanism of Aso caldera. If we can locate the original vents of the four units of pyroclastic flows and falls from Aso caldera, we may better understand the sequences of formation of this caldera.

The present activities are concentrated at the middle region $(* \mathrm{M})$. According to Sudo et al. [2006], these activities originate from a magma reservoir situated at a depth of $5 \sim 6 \mathrm{~km}$. It is not clear whether the present condition of Aso caldera is in the process of developing activities of the component caldera $(* \mathrm{M})$, or it is in its post-caldera activities.

(b) Aira caldera, Kyushu: measures $20 \times 20 \mathrm{~km}^{2}$ in dimension. This caldera is located at the northernmost part of the Kagoshima bay. Gravity anomaly there reaches about $40 \mathrm{mGal}$, and relatively low at the center. The gravity was measured at the sea surface, and the resolution was not adequate to distinguish any component calderas. The two component ones, $(* \mathrm{~W})$ and $(* E)$ are derived from topographic features in Figure 3b. Yokoyama and Ohkawa [1986] analyzed the gravity anomalies observed in the caldera area and evaluated the subsurface structure of the caldera as follows: the caldera deposits of low density extend to a depth of $2.5 \mathrm{~km}$ and are underlain with basement rocks that possibly form a funnel-shape. In the component caldera $(* \mathrm{~W})$, there is flat bottom of about $140 \mathrm{~m}$ (b.s.l.). In $(* \mathrm{E})$ region, there is also flat bottom of $200 \mathrm{~m}$ (b.s.1.). Such flat floors are characteristic of calderas as mentioned in Section 4.1. And at the eastern part, an active vent " $T$ " and two extinct vents exist. It is assumable that region $(* \mathrm{E})$ is younger than $(* \mathrm{~W})$ because " $\mathrm{T}$ " is the last remnant of the activities in this area.

About 29 ka BP, during the period of the caldera formation, the eruptive activity generated a volcanic succession of 4 different units composed of pumice fall layers, pyroclastic flow deposits and co-ignimbrite ashfalls. The total volume of these ejecta amounts to 100 $\mathrm{km}^{3}$ DRE. Their original vents are not accurately located because the majority of the caldera is currently under the sea. The drilling site $(\oplus$ symbol in Figure $3 b)$ is near the west shore of the island of Sakurajima volcano, a post-caldera cone just outside the assumed

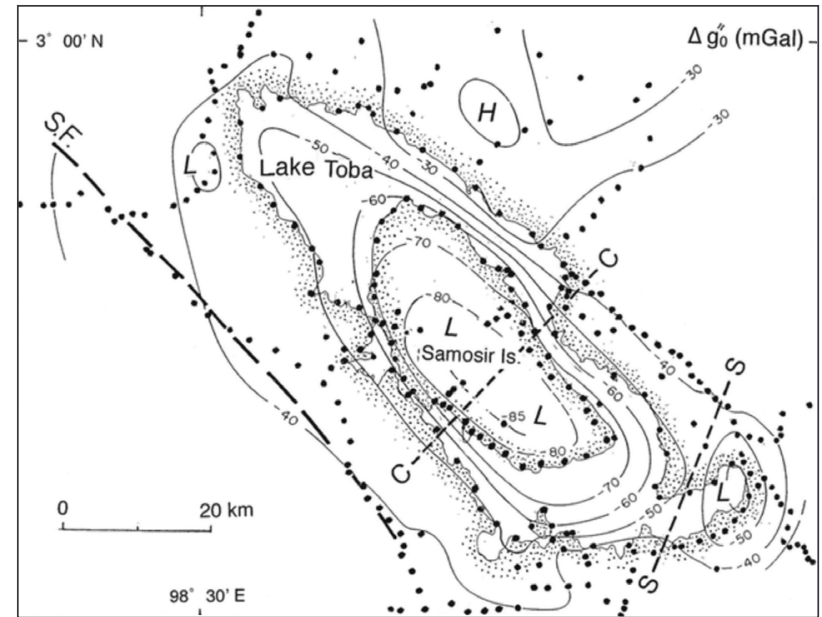

Figure 4. Composite caldera in Lake Toba, Sumatra: distribution of Bouguer gravity anomalies. CC- and SS-lines denote probable boundaries of hypothetical component calderas.

caldera rim. The drilling reaches a depth of $810 \mathrm{~m}$ (b.s.1.). Almost all drilled cores are composed of tuff, welded tuff and pyroclastics and it is not clear whether this site is inside the caldera or not. Sakurajima volcano began its activity $22 \mathrm{ka} \mathrm{BP}$ as a parasite, probably just outside of Aira caldera. North Peak of the volcano is extinct, while South Peak has been active and repeatedly erupted since 1955 .

(c) Toba caldera, Sumatra: one of the largest calderas on Earth measuring roughly $20 \times 80 \mathrm{~km}^{2}$. Its long axis is parallel to the Sumatra fault (S.F. in Figure 4). The lake level is $906 \mathrm{~m}$ (a.s.1.) and the summit of Samosir Island is about $1916 \mathrm{~m}$ (a.s.l.) at the northern part. According to Bemmelen [1949], in Late Pleistocene, siliceous magma rose beneath the present site of Lake Toba and paroxysmal explosions discharged roughly $2 \times 10^{3} \mathrm{~km}^{3}$ of pumiceous tuffs. Later the new magma pushed up the floor producing resurgent domes and resulted in Samosir Island. Nishimura et al. [1984] carried out gravity surveys at 332 points in this area for the period 1976 1980. Yokoyama et al. [1984] supplemented the surveys at 68 points mainly at the central part in 1982. All the results of Bouguer anomalies are simplified and shown in Figure 4. In the figure, the residual gravity anomalies reach $-30 \sim-85 \mathrm{mGal}$ on and around Lake Toba. These anomalies are corrected for the topographies and display the structure below the sea level. A gravity-low at the SE end of the lake suggests a component caldera of about $15 \mathrm{~km}$ across, and after the analogy of Aso and Aira calderas, another large and wide anomaly may be due to 2 component calderas probably bounded by the CC- and SS-lines. Gravity points are not enough in number, especially in the central part of the Samosir Island. In order to advance detailed interpretation, more dense gravity surveys are desirable. 


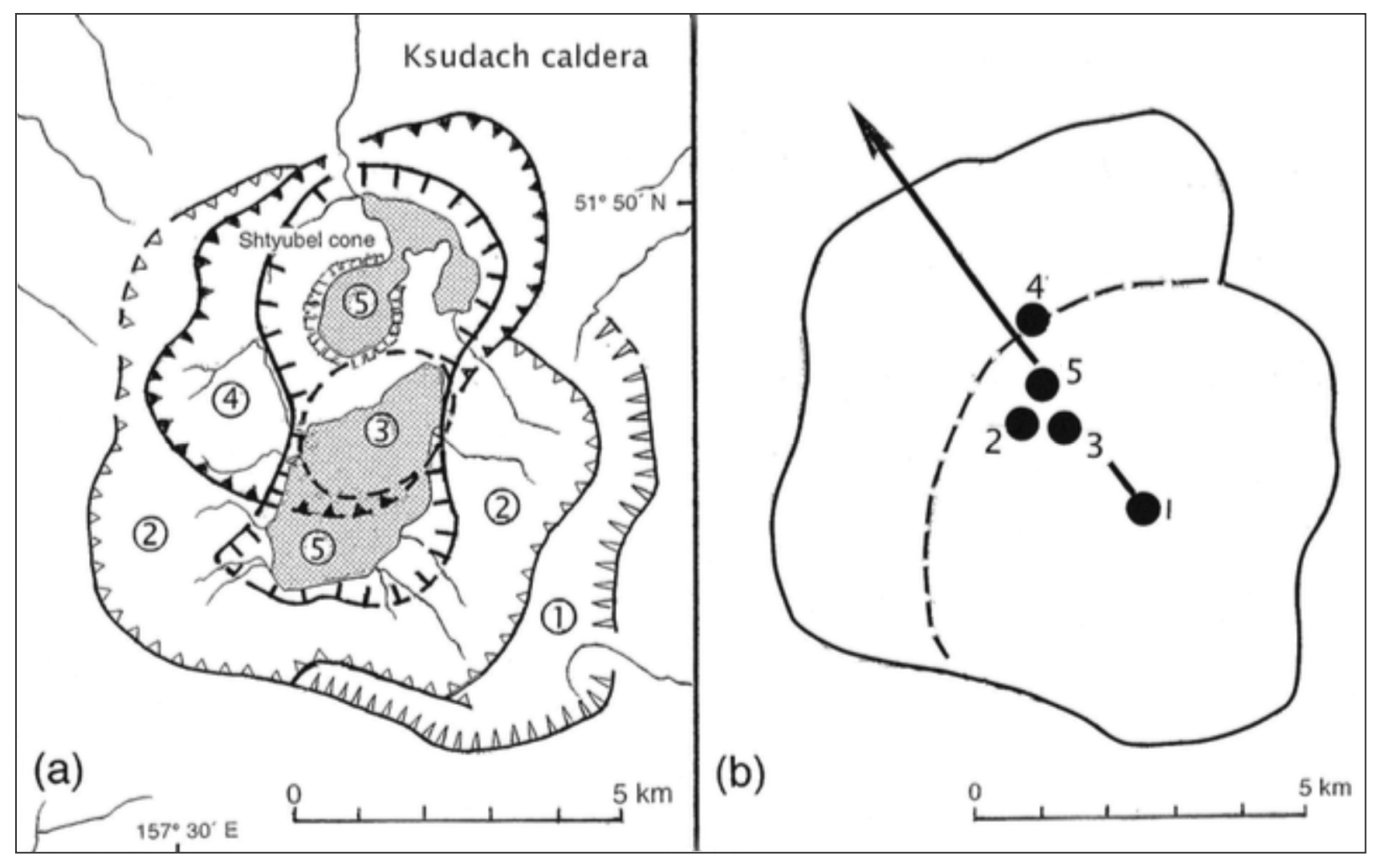

Figure 5. Ksudach caldera, Kamchatka. (a) Caldera areas of the five component calderas after Braitseva et al. [1996]. (b) Migration of the centers of component calderas. The arrow shows a synthesized migratory direction.

\subsection{Calderas under enlargement}

If some calderas are recognized as composite calderas, there should be component calderas undergoing enlargement. Here, we suggest Ksudach caldera, Kamchatka as a unique example of such enlargements. According to Braitseva et al. [1996], the caldera boundaries at each period are shown in Figure $5 \mathrm{a}$, and $(1)$ and (2) formed earliest during Pleistocene time, and subsequently, (3) in $8.8 \sim 8.7 \mathrm{ka} \mathrm{BP}$, (4) in $6 \sim 6.1 \mathrm{ka} \mathrm{BP}$ and (5) in $4 \sim 4.3 \mathrm{ka}$ BP. After formation of (5), Shtyubel' cone has been active, leading to the 1907 eruption. It may be probable that the center of component caldera had migrated, as schematically shown in Figure $5 \mathrm{~b}$ where black dots denote the centers of component calderas. The southeastern part bounded by a broken line approximately shows the first caldera area (1) and the solid line outlines the present caldera boundary. During these periods, the caldera area has been roughly doubled. Volynets et al. [1999] applied geological, tephrochronological and geochemical methods to reconstruct the eruptive history of this caldera during the Holocene period and presented sequence of five events, as shown in Figure 5a. Macias and Sheridan [1995] studied the products of the 1907 eruption of Shtyubel' volcano and estimated the ejecta volume at $2.4 \mathrm{~km}^{3}$ bulk, roughly a half of that for the 1991 eruption of Pinatubo (Table 1). At Ksudach caldera, eventually, several component calderas shall be successively merged into a larger caldera.

\section{Concluding remarks}

In the Introduction of the present paper, transitions in the classification of calderas are traced, and "collapse model" of caldera formation proposed by Fouqué [1879] who interpreted his observation on Santorini caldera is criticized and its validity is questioned on the basis of mainly subsurface structure of the caldera. In the present paper, calderas are first classified into two types, LGA-type and HGA-type, according to subsurface structure. Though the former is more abundant in number than the latter, the calderas of these two types have their own characteristics in explosivity, caldera deposits, and magma reservoirs. Since the 19th century, four large volcanic eruptions resulting in formation of calderas were observed with the scientific understanding that prevailed at that time and are considered to provide reliable data. Thus, these four calderas are critically compared and analyzed from geophysical viewpoints. Their eruptions were all tremendously violent and their activities were realistically reported; however, it is difficult to settle the time of "collapses" during or after the eruptions.

Calderas of HGA-type usually originate from summit reservoirs with basaltic magmas at shallow depths $(\leqslant 5 \mathrm{~km})$, while those of LGA-type are usually underlain by deeper reservoirs of $5 \sim 10 \mathrm{~km}$ depth with silicic magmas. Such differences cause activities to differ in the caldera formation between the two types. Calderas of HGA-type have not demonstrated their formation stages in our history. Only their ensuing activities were observed on some calderas of this type: their magmas are usually basaltic and activities are not very violent. Hence, calderas can form mainly by gravitational collapse or subsidence, compensating magma depleted from the reservoirs during eruptions. The role 
of "explosions" is rather small in such processes. This is a caldera of HGA-type.

On the other hand, historical cases of LGA-type calderas studied in this work indicate that silicic magma reservoirs are usually located at $5 \sim 10 \mathrm{~km}$ depth and highly pressurized magmas play an important role in the caldera formation, as well as, the volume of the ejecta. Physical and chemical properties of magmas depend on their depths and consequently may have much importance to the discussions of caldera formations. "Magmatic explosions" accompanied by a large amount of pyroclastic ejecta mainly contribute to the formation of calderas, larger than $2 \mathrm{~km}$ and maximum of 10 $\mathrm{km}$ in diameter. "Collapses" contribute to deposition of caldera deposits or fallbacks of disrupted volcano edifices, not to compensation for gaps produced in the magma reservoirs. This is a caldera of LGA-type. Large calderas of $10 \sim 20 \mathrm{~km}$ in diameter would be formed by successive merging of adjacent component calderas of LGA-type after a lengthy period of time. These are composite calderas.

In conclusion, some calderas are formed mainly by gravitational collapses, and others are mainly by explosions. Both "collapses" and "explosions" are essential factors that contribute to caldera formation. Variable circumstances emphasize one process or the other.

Acknowledgements. The present author owes his knowledge on various aspects of many calderas to innumerable pioneering researchers and wishes to express his cordial thanks to them. The author is obliged to mention only the references directly related to the present discussion. The author is grateful to Prof. V.V. Ponomareva who gave him introductory knowledge of Ksudach caldera. The author expresses his heartfelt thanks to Dr. R.Y. Koyanagi who kindly contributed to improve the quality of the paper. Thanks also due to the two anonymous referees and Dr. G. De Astis for their critical comments on the early manuscript, which led to many improvements.

\section{References}

Abe, K. (1992). Seismicity of the caldera-making eruption of Mount Katmai, Alaska in 1912, B. Seismol. Soc. Am., 82, 175-191.

Bemmelen, R.W. van (1949). Geology of Indonesia, The Hague: Govt. Printing Office, 707 p.

Braitseva, O.A., I.V. Melekestsev, V.V. Ponomareva and V.Yu. Kirianov (1996). The caldera-forming eruption of Ksudach volcano about cal. A.D. 240: the greatest explosive event of our era in Kamchatka, Russia, J. Volcanol. Geoth. Res., 70, 49-66.

Budetta, G., D. Condarelli, M. Fytikas, N. Kolios, G. Pascale, A. Rapolla and E. Pinna (1984). Geophysical prospecting on the Santorini islands, B. Volcanol., 47, 447-466.

Decker, R.W. (1987). Dynamics of Hawaiian volcanoes: An overview, In: R.W. Decker, T.L. Wright and P.H.
Stauffer (eds.), Volcanism in Hawaii, USGS Prof. Paper 1350, 997-1018.

Eichelberger, J.C., and P.E. Izbekov (2000). Eruption of andesite triggered by dyke injection: contrasting cases at Karymsky Volcano, Kamchatka and Mt Katmai, Alaska, Phil. Trans. R. Soc. Lond. A, 358, 14651485 .

Filson, J., T. Simkin and L.-k. Leu (1973). Seismicity of a caldera collapse: Galapagos Islands 1968, J. Geophys. Res., 78, 8591-8622.

Fisk, R.S., and W.T. Kinoshita (1969). Inflation of Kilauea Volcano prior to its 1967-1968 eruption, Science, 165, 341-349.

Fouqué, F. (1879). Santorin et ses éruptions, G. Macon, Paris, 440 p.; translated and annotated by A.R. McBirney (1998), The Johns Hopkins University Press, Baltimore, $495 \mathrm{p}$.

Geshi, N., and T. Oikawa (2008). Phreatomagmatic eruptions associated with the caldera collapse during the Miyakejima 2000 eruption, Japan, J. Volcanol. Geoth. Res., 176, 457-468.

Gorshkov, G.S. (1959). Gigantic eruption of the Volcano Bezymianny, B. Volcanol., 20, 77-109.

Gottsmann, J., and J. Martí, eds. (2008). Caldera volcanism: analysis, modeling and response, Elsevier, Amsterdam, 487 p.

Gregg, P.M., S.L. de Silva, E.B. Grosfils and J.P. Parmigiani (2012). Catastrophic caldera-forming eruptions: Thermomechanics and implications for eruption triggering and maximum caldera dimensions on Earth, J. Volcanol. Geoth. Res., 241-242, 1-12.

Hallinan, S., and G. Brown (1995). Incremental collapse and stratocone growth within a funnel-shaped caldera, Guayabo, Costa Rica, J. Volcanol. Geoth. Res., 67, 101-122.

Harjono, H., M. Diament, L. Nouaili and J. Dubois (1989). Detection of magma bodies beneath Krakatau volcano (Indonesia) from anomalous shear waves, J. Volcanol. Geoth. Res., 39, 335-348.

Heiken, G., and F.Jr. McCoy (1984). Caldera development during the Minoan eruption, Thira, Cyclades, Greece, J. Geophys. Res., 89, 8441-8462.

Hildreth, W. (1983). The compositionally zoned eruption of 1912 in the Valley of Ten Thousand Smokes, Katmai national park, Alaska, J. Volcanol. Geoth. Res., 18, 1-56.

Hildreth, W., and J. Fierstein (2000). Katmai volcanic cluster and the great eruption of 1912, Geol. Soc. Am. B., 112, 1594-1620.

Hildreth, W., and J. Fierstein (2012). The NovaruptaKatmai eruption of 1912 - Largest eruption of the twentieth century: Centennial perspectives, USGS Prof. Paper 1791, 259 p. 
Hoshizumi, H., K. Watanabe, K. Sakaguchi, K. Uto, K. Ono and T. Nakamura (1997). Aso-4 pyroclastic deposits found by a deep drilling in Aso caldera, Volcanol. Soc. Jap. Abstract, A05 (in Japanese).

Jaxybulatov, K., I. Koulakov, M.I. Seht, K. Klinge, C. Reichert, B. Dahren and V.R. Troll (2011). Evidence for high fluid/melt content beneath Krakatau volcano (Indonesia) from local earthquake tomography, J. Volcanol. Geoth. Res., 206, 96-105.

Kandlbauer, J., and R.S.J. Sparks (2014). New estimates of the 1815 Tambora eruption volume, J. Volcanol. Geoth. Res., 286, 93-100.

Komazawa, M. (1995). Gravimetric analysis of Aso volcano and its interpretation, J. Geod. Soc. Japan, 41, $17-45$.

Lipman, P.W., and D.R. Mullineaux, eds. (1981). The 1980 eruptions of Mount St. Helens, Washington, USGS Prof. Paper 1250, 844 p.

Lipman, P.W. (1997). Subsidence of ash-flow calderas: relation to caldera size and magma-chamber geometry, B. Volcanol., 59, 198-218.

Macias, J.L., and M.F. Sheridan (1995). Products of the 1907 eruption of Shtyubel' Volcano, Ksudach Caldera, Kamchatka, Russia, Geol. Soc. Am. Bull., 107, 969-986.

Matumoto, T. (1971). Seismic body waves observed in the vicinity of Mount Katmai, Alaska, and evidence for the existence of molten chambers, Geol. Soc. Am. B., 82, 2905-2920.

McQuillin, R., and J. Tuson (1965). An interpretation from gravity measurements of the sizes of some British Tertiary granites, Proc. Geol. Soc., 1621, 59-60.

Mori, J., D. Eberhart-Phillips and D.H. Harlow (1996). Three-dimensional velocity structure at Mount Pinatubo: Resolving magma bodies and earthquake hypocenters, In: C.G. Newhall and R.S. Punongbayan (eds.), Fire and Mud, Eruptions and lahars of Mount Pinatubo, Philippines, Univ. Washington Press, 371-382.

Newhall, C.G., and S. Self (1982). The Volcanic Explosivity Index (VEI): An estimate of explosive magnitude for historical volcanism, J. Geophys. Res., 87, 1231-1238.

Newhall, C.G., and R.S. Punongbayan, eds. (1996). Fire and Mud, Eruptions and lahars of Mount Pinatubo, Philippines, Univ. Washington Press., 1126 p.

Nishimura, S., E. Abe, J. Nishida, T. Yokoyama, A. Dharma, P. Hehanussa and F. Hehuwat (1984). A gravity survey and volcanostratigraphic interpretation of the Lake Toba region, North Sumatra, Indonesia, Tectonophysics, 109, 253-272.

Roche, O., T.H. Druitt and O. Merle (2000). Experimental study of caldera formation, J. Geophys. Res.,
105, 395-416.

Scott, W.E., R.P. Hoblitt, R.C. Torres, S. Self, Ma. M.L. Martinez and T.Jr. Nillos (1996). Pyroclastic flows of the June 15, 1991, climactic eruption of Mount Pinatubo, In: C.G. Newhall and R.S. Punongbayan (eds.), Fire and Mud, Eruptions and lahars of Mount Pinatubo, Philippines, Univ. Washington Press, 545-570.

Self, S., M.R. Rampino, M.S. Newton and J.A. Wolff (1984). Volcanological study of the great Tambora eruption of 1815, Geology, 12, 659-663.

Simkin, T., and R.S. Fiske (1983). Krakatau 1883: The volcanic eruption and its effects, Smithsonian Institution Press, $464 \mathrm{p}$.

Steinberg, G.S. (1974). On explosive caldera formation, Modern Geology, 5, 27-30.

Sudo, Y., T. Tsutsui, M. Nakaboh, M. Yoshikawa, S. Yoshikawa and H. Inoue (2006). Ground deformation and magma reservoir at Aso volcano: Location of deflation source derived from long-term geodetic surveys, J. Volcanol. Soc. Jpn., 51, 291-309 (in Japanese with English abstract).

Symons, G.I., ed. (1888). The eruption of Krakatoa, and subsequent phenomena. Report of the Krakatoa Committee of the Royal Society, Trübner and Co. London, $494 \mathrm{p}$.

Timoshenko, S.P., and J.N. Goodier (1970). Theory of elasticity, McGraw-Hill Book Co., New York, 567 p.

Tsuya, H. (1955). Geological and petrological studies of volcano Fuji, V. 5. On the 1707 eruption of volcano Fuji, B. Earthq. Res. Inst., 33, 377-383.

Verbeek, R.D.M. (1885). Krakatau. Batavia, 495 p.

Volynets, O.N., V.V. Ponomareva, O.A. Braitseva, I.V. Melekestsev and Ch.H. Chen (1999). Holocene eruptive history of Ksudach volcanic massif, South Kamchatka: evolution of a large magmatic chamber, J. Volcanol. Geoth. Res., 91, 23-42.

Ward, P.L., A.M. Pitt and E. Endo (1991). Seismic evidence for magma in the vicinity of Mt. Katmai, Alaska, Geophys. Res. Lett., 18, 1537-1540.

Williams, H. (1941). Calderas and their origin, B. Dep. Geol. Sci. Univ. Calif. Publ., 25, 239-346.

Williams, H., and A.R. McBirney (1979). Volcanology, Freeman, Cooper \& Co., San Francisco, 395 p.

Yokoyama, I. (1963). Structure of calderas and gravity anomaly, B. Volcanol., 26, 67-72.

Yokoyama, I., and V. Bonasia (1978). Gravity anomalies on the Thera Islands. Thera and the Aegean world I, 147-150.

Yokoyama, I. (1981). A geophysical interpretation of the 1883 Krakatau eruption, J. Volcanol. Geoth. Res., 9, 359-378.

Yokoyama, I., A. Sudradjat, H. Said and T. Maekawa 
(1984). Formation of volcanic depressions - Krakatau and Toba - Geophysical studies on volcano-tectonic depressions in Indonesia, Interim report of Grantin-Aid for overseas research in 1982 and 1983, Hokkaido Univ., 19-24.

Yokoyama, I., and S. Ohkawa (1986). The subsurface structure of the Aira caldera and its vicinity in southern Kyushu, Japan, J. Volcanol. Geoth. Res., 30, 253-282.

Yokoyama, I., and M. Mena (1991). Structure of La Primavera caldera, Jalisco, Mexico, deduced from gravity anomalies and drilling results, J. Volcanol. Geoth. Res., 47, 183-193.

Yokoyama, I. (2001). The largest magnitudes of earthquakes associated with some historical volcanic eruptions, Annali di Geofisica, 44 (5/6), 1021-1029.

Yokoyama, I. (2002). Classification of calderas based upon subsurface structure with relation to the 2000 Miyakejima eruption, Geophys. B. Hokkaido Univ., 65, 157-166 (in Japanese with English abstract).

Yokoyama, I. (2014). Krakatau caldera deposits: revisited and verification by geophysical means, Annals of Geophysics, 57 (5), S0541; doi:10.4401/ag-6404.

Yokoyama, I. (2015a). Eruption products of the 1883 eruption of Krakatau and their final settlement, Annals of Geophysics, 58 (2), S0220; doi:10.4401/ag6529.

Yokoyama, I. (2015b). Eruption pattern of parasitic volcanoes, Annals of Geophysics, 58 (3), S0327; doi:10.4401/ag-6557.

Corresponding author: Izumi Yokoyama,

The Japan Academy, Ueno Park, Tokyo, Japan;

email: iyokoyama@joy.ocn.ne.jp.

(C) 2016 by the Istituto Nazionale di Geofisica e Vulcanologia. All rights reserved. 